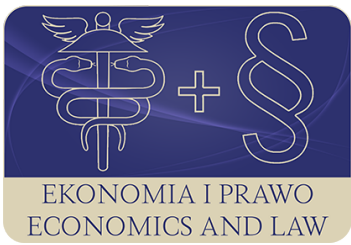

EKONOMIA I PRAWO. ECONOMICS AND LAW

Volume 20, Issue 3, September 2021

p-ISSN 1898-2255, e-ISSN 2392-1625

www.economicsandlaw.pl

ORIGINAL ARTICLE

received 30.03.2021; revised 10.09.2021; accepted 30.09.2021

Citation: Legiędź, T. (2021). The impact of Covid-19 pandemic on the institutional change in developing countries. Ekonomia i Prawo. Economics and Law, 20(3), 587-601. https://doi.org/10.12775/EiP.2021.035.

\title{
The impact of Covid-19 pandemic on the institutional change in developing countries
}

\author{
TOMASZ LEGIĘDŹ \\ University of Lodz, Faculty of Economics and Sociology, Department of Development Economics, \\ ul. POW 3/5, 90 -255 Łódź, Poland \\ ๑ legiedz@uni.lodz.pl \\ Dorcid.org/0000-0001-9396-0729
}

\begin{abstract}
Motivation: The Covid-19 pandemic is having a critical impact on economies, especially in developing countries. Such a serious external shock affects the distribution of economic rents, thus leading to potentially large institutional changes. Naturally, in the short term we are dealing with an economic crisis and a restriction of civil liberties in both autocratic and democratic countries, however, it is not known what the dynamics of institutional changes will be in the longer run.
\end{abstract}

Aim: The main purpose of the article is to answer if the Covid-19 pandemic becomes a turning point that will determine the institutional system in developing countries for the next few decades. The first part of the article outlines the theory of institutional change, with particular emphasis on the role of external shocks. The next section presents studies on the socioeconomic impact of two major epidemics: The Black Death and the Great Influenza Pandemic. The third part conducts an assessment as to what extent the current pandemic may affect institutions in developing countries, by reference to the example of two countries: Tunisia and Cambodia. The analysis is conducted from the perspective of the new institutional economics.

Results: If we look at the experiences from previous pandemics, current events and refer to the literature on the theory of institutional change, we can conclude that significant institutional changes caused by Covid-19 are unlikely. The process of institutional change

is characterized by a specific complexity and changing dynamics. Nonetheless, it is the internal factors, reflecting the actions of people trying to maximize the benefits, which are the main cause of change in an institutional system. Therefore, the Covid-19 pandemic 
is more likely to strengthen the endogeneity of the process of institutional change, rather than change its course.

Keywords: Covid-19; economic development; new institutional economics; institutions; institutional change JEL: O43; B52; Pl6

\section{Introduction}

The Covid-19 pandemic triggered a global economic crisis which caused a recession in many countries. The IMF (2021, p. 8) estimates that the global economy shrunk by $3.3 \%$ in 2020. This is the worst decline since the Great Depression of the 1930s. Although in the case of the economies in developing countries, the decrease in production was smaller $(2.2 \%)$ compared to that of developed countries (4.7\%), the negative effects of the pandemic may last longer due to a lower level of economic development (IMF, 2021; Rodela et al., 2020). The institutional systems of developing countries are less stable and therefore they are especially prone to external shocks. Therefore, a question may arise whether, in the case of some countries, the Covid-19 pandemic will become a turning point that will determine what form the institutional system will take in the next few decades? On the one hand, a pandemic may strengthen autocratic and oligarchic systems, but on the other hand, it may also block such a process and accelerate the opening of political and economic systems. The main purpose of the article is an attempt to answer this question.

The first part of the article outlines the theory of institutional change, with particular emphasis on the role of external shocks. The next section presents studies on the socio-economic impact of two major epidemics: The Black Death and the Great Influenza Pandemic. The third part conducts an assessment as to what extent the current epidemic may affect institutions in developing countries, by reference to the example of two countries: Tunisia and Cambodia. The analysis is conducted from the perspective of the new institutional economics, mainly the theoretical concept by Aoki (2001; 2007), Greif (2006), Greif \& Laitin (2004) and North (1990, 2005). The article uses the qualitative analysis method that includes literature review, descriptive analysis, and short case studies. The applied method involves deductive analysis, as well as the analysis of cause-effect relationships concerning the impact of the recent Covid-19 pandemic on the further economic and political development of the developing world.

\section{The institutional change: the role of the exogenous shocks}

Today, most economists agree that the institution significantly affects economic development (Acemoglu \& Robinson, 2012; Acemoglu et al., 2005; Baland et al., 2020; Chang, 2007; North, 1990; 2005; Rodrik et al., 2004; Shirley, 2008; Toye, 1997). However, the question arises of how an institutional system that 
is beneficial for development is created. To answer this question, economists try to attain a better understanding of the process of institutional change. It is recognized that institutions can change due to endogenous processes, exogenous shocks, and combinations of both. The endogenous explanations of institutional change, refer to dynamic processes that occur within the institution itself. By contrast, the exogenous explanation assumes that institutions change as a result of interaction with the outside world. In a state of institutional equilibrium, people show a natural tendency to follow the formal and informal rules constituting an institutional system. This system will be stable because no agent can increase its utility by unilateral action (e.g., it does not have sufficient power to effect such a change $)^{1}$. Transformations in the institutional structure will take place when the current pattern of conduct does not guarantee the individual that others will act in the same way.

According to North (1990, p. 84), relative price changes are the main source of institutional change. Some of those relative price changes will be exogenous (e.g. an epidemic or a new technological innovation), however, "most will be endogenous, reflecting the ongoing maximizing efforts of political and economic agents" (North, 1990, p. 84). Institutions create a structure of incentives for people, to which they adapt to maximize utility. If some of the actions are more profitable, people will be to invest in them more willingly. North (2005, p. 61) states that "if the highest return in an economy is to piracy we can expect that the organizations will invest in skills and knowledge that will make them better pirates". People will not become better pirates just because social norms cause institutional changes prohibiting piracy ${ }^{2}$. However, North believed that due to imperfect markets, limited rationality, path dependence and ideological prejudices, people find it difficult to change institutions in the way they want. The cost of changing institutions may also be influenced by economic growth or decline, e.g., the increase in welfare may render building some institutions profitable but not other ones ${ }^{3}$.

According to Aoki (2001, p. 239), changes to institutions will be attempted when the existing set of rules does not give satisfactory results in relation to an agent's aspirations. He refers to the emergence of a gap between aspirations and achievements as a general cognitive disequilibrium. That disequilibrium "could happen when there is a drastic environmental change, along with cumulative dynamic outcomes affecting the objective structure of the game" (Aoki, 2001, p. 240). Environmental factors that may trigger change include new technological innovation, expansive external market exchange, external shocks (such as

${ }^{1}$ As Aoki (2001, p. 232) writes, if we are dealing with a Nash equilibrium, a one-sided change of strategy will not be profitable to any rational entity. However, it can be assumed that if the sets of all possible actions of agents are objectively known and established, some might see a possibility of a "better balance".

2 This is how North (1990, p. 24) explains, for example, why slavery was banned.

3 According to Chang (2007, p. 27), institutional changes and economic development influence each other, with complex chains of causality. 
the defeat at war), and a large-scale institutional change occurring in a neighbouring domain. However, Aoki (2001, p. 241) believes that the process of institutional change is caused by the combined effects of endogenous and external factors. "External shocks alone may not be sufficient to trigger institutional change" if some symptoms of institutional change have not been visible before (Aoki, 2001, p. 240). In such a situation, agents can only marginally adjust their subjective game models in response to even severe external shocks.

The explanation of the institutional change is closely related to the definition of what institutions are, specifically to their exogenous or endogenous nature. There are two main views on how institutions are defined in the new institutional economics: an "institutions-as-rules" approach and an "institutions-as-equilibria" approach. An "institutions-as-rules" approach identifies institutions as the rules of the game in a society, including both formal rules, and informal, which are generally enforced by the members of society (North, 1990, p. 36). An "institutions-as-equilibria" approach focuses on how interactions among purposeful agents create the structure that gives each of them the motivation to act in a manner perpetuating institutions (Aoki, 2001; 2007; Greif, 2006; Greif \& Kingston, 2011). In the case of an "institutions-as-rules" approach, institutions are imposed from the outside, while the "institutions-as-equilibria" theorists emphasize their endogenous nature. As shown earlier, both approaches indicate that institutional change may have an exogenous as well as an endogenous source. North does not explain the political, social, or economic factors underlying the shift in moral preferences (Faundez, 2016, p. 396). According to Greif (2006, p. 7), the definition of "institutions-as-rules" means that all too often institutions are identified with the politically defined rules which are imposed "from the top" by the authorities. Such research perspective limits the possibility of studying the process of institutional changes, because informal institutions constituting an important part of the institutional system are thereby treated as an exogenous variable and, to a certain extent, are excluded from the analysis. The changes might be endogenous in nature provided there are institutions that open up new opportunities and motivate people to experiment, create new organizations and develop further knowledge. Then the institutional environment enhances the chances of inventing new technologies that significantly alter the subject and the type of the transaction or stimulate the creation of organizations that cause the process of change to be continued. However, new institutions replacing the old ones are not only a reflection of the changed conditions of making transactions, and the interests of existing organizations, but they are still burdened with the legacy of the pre-existing rules and standards of conduct (Greif, 2006, p. 188).

While emphasising the importance of the external factors influencing the process of institutional changes, it is also worth mentioning the concept of critical juncture ${ }^{4}$. This concept refers to situations of uncertainty in which

4 The concept of critical juncture is essential to historical institutionalism (Capoccia \& Kelemen, 2007, p. 341). 
decisions of significant actors are causally crucial for the selection of one path of institutional development over other possible paths. The proponents of the concept of critical juncture argue that if institutions reinforce themselves endogenously, only an unpredictable event from outside can disrupt that process (Koning, 2016, p. 644). This kind of explanation provides a clear starting point for the causal narrative and as such an identifiable "starting cause" of change. For example, the Black Death killed so much population that it forced changes in the feudal system of medieval Europe ${ }^{5}$. Junctures are of key importance in understanding the institutional change because they place institutional arrangements on paths or trajectories, which are then very difficult to alter (Pierson, 2004, p. 135).

\section{From the Black Death to the Great Influenza Pandemic}

The Covid-19 pandemic broke out a little over a year ago. Since it is currently virtually impossible to accurately assess its long-term institutional effects, it is necessary to refer to the examples of epidemics that occurred earlier. In the context of their impact on socio-economic systems, The Black Death and the Great Influenza Pandemic are the most frequently studied epidemics in the literature on the subject.

\subsection{The Black Death}

Some of the structural and institutional changes, crucial for the subsequent economic domination of Europe, took place quite early, and some researchers believe that the factor that triggered the process of institutional changes was the exogenous demographic shock created by the Black Death (Epstein, 2000; Herlihy, 1997). The Black Death, or the bubonic plague epidemic, occurred in Afro-Eurasia from 1346 to 1353. It is estimated that it led to the death of 30$60 \%$ of the European population (Alchon, 2003, p. 21). The radical decline in the population caused wage growth, which, in turn, forced several institutional changes, which later proved to have far-reaching consequences (Pamuk, 2007, p. 312). The Black Death brought about changes in rural as well as urban areas which paved the way not only for the increasing commercialization of agriculture but also manufacturing and trade in cities. The shortage and high costs of manpower initiated the era of technological innovations aimed at conserving manpower.

The example of the Black Death is also mentioned by Acemoglu \& Robinson (2012, p. 101), who argue that minimal differences in the initial conditions combined with an external shock may become a turning point which translates into the adoption of a completely different path of institutional development. Before the outbreak of the plague, the political and economic institutions

5 The significance of critical juncture is also indicated in Acemoglu \& Robinson's (2012) theory. 
in Western and Eastern Europe did not differ significantly from each other. The serfdom system was the predominant one. Peasants were tied to the land and were not allowed to change their place of residence without the consent of the landowner. The epidemic drastically reduced the number of able-bodied workers, which led to an increase in the bargaining power of the peasants. They began to demand changes and the feudal lords, who needed a workforce (because of numerous peasant uprisings), finally started to concede. Serfdom started to be replaced with rents. Hereditary lease agreements appeared, which regulated the relations between the landowner and the peasant. Similarly, because of the epidemic, the power of city merchants increased, and they became more independent from feudal lords. This process is believed to have taken place all over Western Europe. The situation looked different in the more sparsely populated Eastern Europe, where a less invasive bacterial strain spread, as a result of which the Black Death had a significantly weaker influence on the institutional system. According to Piątkowski (2018, p. 64), the peasants in Eastern Europe never achieved the critical mass that would allow them to fight for a better political position.

The Black Death had an unquestionable impact on the institutional systems of Europe at the time, but some researchers consider the institutional changes which occurred in the wake of the epidemic to be more regionally varied. According to Cohn (2007), Western European monarchies and municipalities adopted diverse legislative acts in response to manpower shortages and soaring prices caused by epidemics. Some focused on price and wage control, others regulated the mobility of peasants. Some of these new institutions increased the freedoms enjoyed by the peasants and townspeople, others were more stringent. De Keyzer (2013, p. 520) gives an example of Brecklands of Norfolk where, thanks to the Black Death, the feudal lords were able to expand their estates and feudal claims to the detriment of small leaseholders. This unbalanced distribution of power and wealth led to growing conflicts and tensions and lasted until the 18th century. A similar situation occurred in Italy, where strong urban elites responded to labour shortages by adopting restrictive labour laws. At the same time, in the area of the Low Countries, the freedom and mobility of workers increased (van Bavel, 2016, p. 136). In certain parts of Western Europe, the epidemic resulted in greater freedom and higher wages and brought about greater equality, simply because a high degree of self-organization existed previously, granting ordinary people the social and political advantages needed to make use of the labour shortage. The process of departure from feudalism started in some parts of Europe even before the Black Death, as exemplified by the Low Countries (van Bavel \& van Zanden, 2004). That is why van Bavel (2020, p. 5) believes that the impact of even such a severe exogenous shock as the Black Death on the economy and society is limited by the pre-existing institutions. Therefore, an exogenous shock is more likely to strengthen the endogeneity of the process of institutional change, rather than change its course. 


\subsection{The Great Influenza Pandemic}

The influenza pandemic, which broke out in 1918, was the most severe in recent history. It is estimated that the so-called Spanish flu killed at least 40 million people worldwide. The vast majority of the victims were young people between the ages of 15 and 44 (Brainerd \& Siegler, 2003) ${ }^{6}$. In many countries, the pandemic caused a decline in GDP and consumption, by about 6-8\% (Barro et al., 2020). However, the economic and social effects of the Spanish flu were also perceived in the long-term perspective. Almond's (2006) research demonstrated that in the USA, cohorts in utero during the pandemic displayed reduced educational attainment, lower income, lower socioeconomic status compared with other birth cohorts. These adverse effects were also felt by the next generations (Cook et al., 2019). As other studies show, the influenza pandemic brought about similar effects in Sweden (Helgertz \& Bengtsson, 2019; Richter \& Robling, 2013), Korea (Hong \& Yun, 2017), Brazil (Guimbeau et al., 2020), and Taiwan (Lin \& Liu, 2014). Interesting conclusions can be drawn from recent studies on the impact of the 1918 influenza on the Spanish economy (Basco et al., 2021). Spain at the beginning of the 20th century constitutes an interesting example since it resembled modern developing countries. As the number of potential employees is reduced due to the epidemic, it is believed that this type of shock will lead to increasing real wages (as in the case of the bubonic plague pandemic described earlier). In contrast, although Spain was one of the European countries with the highest number of deaths from influenza in 1918, there was a significant, short-term, decline in real daily wages. Additionally, according to this study, influenza probably did not negatively affect the return on capital. This would mean that employees are, after all, more exposed to the negative effects of a pandemic than entrepreneurs.

Although the above studies on the impact of the Spanish flu did not deal with institutional issues directly, it would be difficult to argue that the abovementioned long-term effects of the pandemic did not affect the process of institutional change. In this context, Blickle's (2020) analysis is important, as he showed on the example of the Weimar Republic that the Spanish flu pandemic may result in significant social changes. According to these studies, first, the number of influenza deaths and lower per capita expenditure, especially in the case of services used by young people, were correlated. Second, influenza deaths were correlated with the number of votes received by the extremist National Socialist party in 1932 and 1933. According to Blickle (2020, p. 17), since the pandemic mainly affected a specific part of the demographic spectrum, in this case, younger people, it could have significantly affected the change in people's preferences. An epidemic usually leads to a rising aversion to foreigners and ethnic minorities, which could have additionally contributed to an

6 According to some sources, the number of victims of the pandemic could have been as high as 100 million, or 5\% of the world population at that time (Kupperberg, 2008, p. 64). 
increase in support for right-wing parties in the Weimar Republic ${ }^{7}$. However, it is difficult to clearly define whether the pandemic, in this case, was a decisive factor or merely a factor intensifying the existing process. On the other hand, according to the analysis by Geloso \& Bologna Pavlik (2021), the countries that had higher levels of economic freedom mitigated the damage caused by the Spanish flu pandemic to a greater extent. The same study also points to the conclusion whereby the political system was also important, although to a lesser extent, i.e. in democratic countries the effects of the pandemic were counteracted more effectively (Geloso \& Bologna Pavlik, 2021, p. 261). That is, the greater the scope of political freedoms granted by the institutional system, the easier it was to reduce the negative effects of the external shock. Thus, an exogenous shock itself was not that important to the process of institutional changes. In the case of countries with more repressive institutional systems, the pandemic may have contributed to worsening the situation, although it is difficult to determine whether it reversed the trend of institutional change or only accelerated it.

\section{The impact of the Covid-19 pandemic on the institutional system}

Since the Covid-19 pandemic began just over a year ago, it is difficult to estimate its future impact on the dynamics of the process of institutional changes. At the current stage of the pandemic, researchers are focusing on how individual countries are coping with Covid-19 (Greer et al., 2020). There are opinions that countries with autocratic systems are more effective in fighting the pandemic because it is easier for them to introduce laws restricting civic liberties (Cepaluni et al., 2020; Sorci et al., 2020a, 2020b). Countries with stronger democracies are also slower to react in the face of the pandemic (Sebhatu et al., 2020). The policy of fighting Covid-19 was also influenced by the political cycle. It was the upcoming elections that affected the degree of the applied restrictions, which, as a result, hurt the effectiveness of the struggle against the pandemic (Pulejo \& Querubín, 2020). In the case of this type of research, however, one has to take into account that it was carried out at the initial stage of the pandemic, which affected weaker democracies and autocratic countries to a greater extent only during its further "waves". These studies also run the risk of errors and falsification in reporting cases of infections and deaths (Ashraf, 2020; Tuite, Bogoch, et al., 2020; Tuite, Ng, et al., 2020). While assessing the effectiveness of the fight against a pandemic, many factors should be considered. Even though autocratic China, through radical actions (cutting off Wuhan from the rest of the World), finally managed to quickly reduce the epidemics in the country, it was the lack

7 Some researchers believe that the conditions of the Versailles Treaty in 1919, unfavourable for Germany, were a result of the poor disposition of U.S. President Woodrow Wilson, who suffered from complications after having suffered from influenza (Barro et al., 2020, p. 3). Thus the Great Influenza Pandemic might have indirectly caused World War II. 
of transparency and the initial inaction of the authorities that delayed the decision to stop the epidemic before it spread worldwide (Ang, 2020; Kavanagh, 2020). Taiwan and South Korea, despite being well-functioning democracies, also managed to combat the pandemic successfully. Cassan \& van Steenvoort (2021) believe that if pre-determined characteristics and policy responses are taken into account, the death rates due to Covid 19 show no difference between political regimes. So, if autocratic countries are not better at managing the Covid-19 crisis, it seems that democracies with a more open political and economic system are not so vulnerable to permanent restriction of these liberties, because of the pandemic.

Although the Covid-19 pandemic started just over a year ago, we can already find arguments supporting the hypothesis whereby this exogenous shock will likely not lead to rather drastic institutional changes in either democratic or authoritarian countries. One of the more interesting examples is Tunisia. Ten years have just elapsed since the events that gave rise to the so-called Arab Spring. Tunisia is the only country in the region that has succeeded in replacing an authoritarian regime with a democracy. According to the annual survey Freedom in the World Tunisia is now a free country (Freedom House, 2021). The score of the democracy index in 2020 was 6.59 (compared to 2.79 in 2010), and Tunisia was classified as a flawed democracy (The Economist Intelligence Unit, 2021). However, democratization has not been accompanied by a significant improvement in economic conditions. As a result of the relatively unstable political situation (frequent changes of government and terrorists' threat), the average rate of economic growth under democratic administrations was lower than in the last decade of autocratic rule (World Bank, 202lb). The Covid-19 pandemic hit the Tunisian economy hard and it shrank by as much as $-8.8 \%$ in 2020 (African Development Bank, 2021, p. 11). The large decline in GDP was caused not only by the Covid-19 pandemic, which affected the key tourism sector but was also due to the more stringent financing conditions designed to fight inflation. Tunisia faces a problem of how to deal with a health emergency while preserving the rule of law and democratic changes after the revolution. As Tunisia is a young and not solidified democracy, it should potentially be more exposed to external shocks. At the beginning of 2021, a wave of anti-government demonstrations broke out, one of the main causes of which was the economic situation, e.g., high unemployment of 16.7\% in 2020 (World Bank, 2021b), but also the political situation. However, the discontent and opposition to the political consensus developed over the last decade have long been on the rise. The embodiment of dissatisfaction with the ruling class was the 2019 election of President Kais Saied, who was not affiliated with any political party. Thus, although the economic crisis caused by the pandemic has increased social discontent and protests, most of the dynamics currently characterizing the Tunisian political landscape are firmly rooted in the dynamics that started long before the pandemic began (Cristiani, 2020). 
Another interesting example is the situation in Cambodia. Cambodia had an average real growth rate of 7.7\% between 1998 and 2019 (World Bank, 202lb). Covid-19 posed economic threats to different aspects of Cambodia's growth, with tourism, construction, and manufacturing exports (which together accounted for nearly $40 \%$ of the country's paid employment and over $70 \%$ of its growth in 2019) considered to be the most affected sectors. The economy shrank by as much as $-3.1 \%$ in 2020 (World Bank, 202la). Prime Minister Hun Sen and the ruling Cambodian People's Party are using the pandemic to consolidate their power. However, this process did not start because of the pandemic and has continued in Cambodia for some time. Although Cambodia has never been a fully democratic country, a decade ago citizens could enjoy a greater range of political freedoms (democracy index 4.87 in 2010 compared to 3.10 in 2020 (The Economist Intelligence Unit, 2021). Since the 2013-14 protests, the ruling party has been systematically increasing the repression of the opposition and independent media. In 2017, the Supreme Court delegalized the largest opposition party, thus enabling the Cambodian People's Party to win all seats in the parliament in 2018. Even before the Covid-19 pandemic, in response to the autocratic rule of Hun Sen, the European Union partially suspended preferential access to European markets, later threatening to impose sanctions. Prime Minister Hun Sen, fearing protests related to the deteriorating economic situation, introduced further laws limiting the scope of civil liberties and attacking the media under the pretext of fighting the pandemic. Taking advantage of the new laws, Cambodian authorities detained and jailed numerous activists on spurious charges. In many areas, the Cambodian authorities seem to be inspired by the actions of the Chinese authorities. The impact of the PRC on the economy is increasing, mainly in the real estate and construction sectors. The Chinese are also the majority of tourists who visit Cambodia. Cambodia's external public debt reached US\$7 billion in 2018, of which half is owed to China (World Bank, 2019). As a result of the pandemic, the governments of both countries have strengthened their cooperation (Ciorciari, 2021) ${ }^{8}$. To sum up, in the case of Cambodia, the Covid-19 epidemic did not cause a shock that would have a significant impact on the process of institutional change. The process of consolidating autocratic power and the oligarchizing of the economy began earlier and would have continued even if the pandemic had not begun. However, as could be expected, in Cambodia, as probably in many other autocratic countries, the authorities used the pandemic as a pretext to limit civil liberties, to fight independent media and the opposition, and the process of unfavourable institutional changes accelerated.

8 China's diplomatic activities during the COVID-19 pandemic (e.g. vaccine diplomacy) can also be identified as one of the external factors that may affect the process of institutional change in various countries. In this sense, the COVID-19 pandemic could increase the effectiveness of "promoting" the Chinese model in the world. 


\section{Conclusion}

A cursory analysis of the case of Tunisia and Cambodia, only a little more than a year from the beginning of the pandemic, is not enough to present conclusive arguments supporting the thesis whereby the current epidemic will not significantly affect the process of institutional changes both in these two and the rest of the developing countries. However, if we look at the experiences from previous pandemics and refer to the literature on the theory of institutional change, we can conclude that significant institutional changes caused by Covid-19 are unlikely. The process of institutional change is characterized by a specific complexity and changing dynamics. Nonetheless, it is the internal factors, reflecting the actions of people trying to maximize the benefits, which are the main cause of change in an institutional system. Therefore, the Covid-19 pandemic is more likely to strengthen the endogeneity of the process of institutional change, rather than change its course. Even if we recognize that external factors are also a significant source of that change, then still, the Covid-19 pandemic is just one of many that are currently affecting the institutional systems of developing countries. Looking at the example of Cambodia, but also many other developing countries, the influence of large economic and political powers (e.g., China) seems to be more significant.

\section{References}

Acemoglu, D., \& Robinson, J.A. (2012). Why nations fail: the origins of the power, prosperity, and poverty. Profile Books.

Acemoglu, D., Johnson, S., \& Robinson, J.A. (2005). Institutions as a fundamental cause of long-run growth. In P. Aghion, \& S. N. Durlauf (Eds.), Handbook of economic growth, 1A, 385-472. Elsevier. https://doi.org/10.1016/ S1574-0684(05)01006-3.

African Development Bank. (2021). African economic outlook 2021: from debt resolution to growth: the road ahead for Africa. Retrieved 09.09.2021 from https:// www.afdb.org/en/knowledge/publications/african-economic-outlook.

Alchon, S.A. (2003). A pest in the land: new world epidemics in a global perspective. University of New Mexico Press.

Almond, D. (2006). Is the 1918 influenza pandemic over: long-term effects of in utero influenza exposure in the post-1940 U.S. population. Journal of Political Economy, 114(4), 672-712. https://doi.org/10.1086/507154.

Ang, Y.Y. (2020). When Covid-19 meets centralized, personalized power. Nature Human Behaviour, 4(5), 445-447. https://doi.org/10.1038/ s41562-020-0872-3.

Aoki, M. (2001). Toward a comparative institutional analysis. MIT Press.

Aoki, M. (2007). Endogenizing institutions and institutional changes. Journal of Institutional Economics, 3(1), 1-31. https://doi.org/10.1017/ S1744137406000531. 
Ashraf, B.N. (2020). Devastation caused by Covid-19: is democracy to blame. SSRN Electronic Journal, 1-22. https://doi.org/10.2139/ssrn.3596009.

Baland, J.-M., Bourguignon, F., Platteau, J.-P., \& Verdier, T. (2020). Economic development and institutions: an introduction. In J.-M. Baland, F. Bourguignon, J.-P. Platteau, \& T. Verdier (Eds.), The handbook of economic development and institutions (pp. 1-20). Princeton University Press. https://doi. org/10.2307/j.ctvm7bbxr.4.

Barro, R.J., Ursúa, J.F., \& Weng, J. (2020). The coronavirus and the Great Influenza Pandemic: lessons from the "Spanish flu" for the coronavirus's potential effects on mortality and economic activity. https://doi.org/10.3386/W26866.

Basco, S., Domènech, J., \& Rosés, J.R. (2021). The redistributive effects of pandemics: evidence on the Spanish flu. World Development, 141, 105389. https://doi.org/10.1016/j.worlddev.2021.105389.

Blickle, K. (2020). Pandemics change cities: municipal spending and voter extremism in Germany, 1918-1933. FRB of New York Staff Report, 921, 1-34. https://doi.org/10.2139/ssrn.3592888.

Brainerd, E., \& Siegler, M.V. (2003). The economic effects of the 1918 influenza epidemic. CEPR Discussion Paper, 3791, 1-41.

Capoccia, G., \& Kelemen, R.D. (2007). The study of critical junctures: theory, narrative, and counterfactuals in historical institutionalism. World Politics, 59(3), 341-369. https://doi.org/10.1017/S0043887100020852.

Cassan, G., \& van Steenvoort, M. (2021). Political regime and Covid 19 death rate: efficient, biasing or simply different autocracies. http://arxiv.org/ abs/2101.09960.

Cepaluni, G., Dorsch, M., \& Branyiczki, R. (2020). Political regimes and deaths in the early stages of the Covid-19 pandemic. SSRN Electronic Journal, 1-49. https://doi.org/10.2139/ssrn.3586767.

Chang, H.-J. (2007). Understanding the relationship between institutions and economic development: some key theoretical issues. In H.-J. Chang (Ed.), Institutional change and economic development (pp. 17-34). Anthem Press.

Ciorciari, J.D. (2021). Cambodia in 2020. Asian Survey, 61(1), 123-129. https:// doi.org/10.1525/as.2021.61.1.123.

Cohn, S. (2007). After the Black Death: labour legislation and attitudes towards labour in late-medieval western Europe. The Economic History Review, 60(3), 457-485. https://doi.org/10.1111/j.1468-0289.2006.00368.x.

Cook, C.J., Fletcher, J.M., \& Forgues, A. (2019). Multigenerational effects of early-life health shocks. Demograhy, 56(5), 1855-1874. https://doi. org/10.1007/s13524-019-00804-3.

Cristiani, D. (2020). Tunisia's political landscape a decade after the Jasmine revolution. Retrieved 09.09.2021 from https://www.atlanticcouncil.org/blogs/ menasource/tunisias-political-landscape-a-decade-after-the-jasmine-revolution. 
De Keyzer, M. (2013). The impact of different distributions of power on access rights to the common wastelands: the Campine, Brecklands and Geest compared. Journal of Institutional Economics, 9(4), 517-542. https://doi. org/10.1017/S1744137413000246.

Epstein, S.R. (2000). Freedom and growth: the rise of states and markets in Europe, 1300-1750. Routledge.

Faundez, J. (2016). Douglass North's theory of institutions: lessons for law and development. Hague Journal on the Rule of Law, 8(2), 373-419. https:// doi.org/10.1007/s40803-016-0028-8.

Freedom House. (2021). Freedom in the world. Retrieved 09.09.2021 from https://freedomhouse.org/countries/freedom-world/scores.

Geloso, V., \& Bologna Pavlik, J. (2021). Economic freedom and the economic consequences of the 1918 pandemic. Contemporary Economic Policy, 39(2), 255-263. https://doi.org/10.1111/coep.12504.

Greer, S.L., King, E.J., da Fonseca, E.M., \& Peralta-Santos, A. (2020). The comparative politics of Covid-19: the need to understand government responses. Global Public Health, 15(9), 1413-1416. https://doi.org/10.1080/ 17441692.2020 .1783340$.

Greif, A. (2006). Institutions and the path to the modern economy: lessons from medieval trade. Cambridge University Press. https://doi.org/10.1017/ CBO9780511791307.

Greif, A., \& Kingston, C. (2011). Institutions: rules or equilibria. In N. Schofield, \& G. Caballero (Eds.), Political economy of institutions, democracy and voting (pp. 13-43). Springer. https://doi.org/10.1007/978-3-642-19519-8_2.

Greif, A., \& Laitin, D.D. (2004). A theory of endogenous institutional change. American Political Science Review, 98(4), 633-652. https://doi.org/10.1017/ S0003055404041395.

Guimbeau, A., Menon, N., \& Musacchio, A. (2020). The Brazilian bombshell: the long-term impact of the 1918 influenza pandemic the south American way. NBER Working Paper, w26929, 1-48. https://doi.org/10.3386/ w26929.

Helgertz, J., \& Bengtsson, T. (2019). The long-lasting influenza: the impact of fetal stress during the 1918 influenza pandemic on socioeconomic attainment and health in Sweden, 1968-2012. Demography, 56(4), 1389-1425. https://doi.org/10.1007/s13524-019-00799-x.

Herlihy, D. (1997). The Black Death and the transformation of the west. Harvard University Press. https://doi.org/10.2307/j.ctvjghwgp.

Hong, S.C., \& Yun, Y. (2017). Fetal exposure to the 1918 influenza pandemic in colonial Korea and human capital development. Seoul Journal of Economics, 30(4), 354-383.

IMF. (2021). World economic outlook: managing divergent recoveries. https://doi. org/10.5089/9781513575025.081. 
Kavanagh, M.M. (2020). Authoritarianism, outbreaks, and information politics. The Lancet Public Health, 5(3), el35-el36. https://doi.org/10.1016/ S2468-2667(20)30030-X.

Koning, E.A. (2016). The three institutionalisms and institutional dynamics: Understanding endogenous and exogenous change. Journal of Public Policy, 36(4), 639-664. https://doi.org/10.1017/S0143814X15000240.

Kupperberg, P. (2008). The influenza pandemic of 1918-1919. Chelsea House.

Lin, M.J., \& Liu, E.M. (2014). Does in utero exposure to illness matter: the 1918 influenza epidemic in Taiwan as a natural experiment. Journal of Health Economics, 37(1), 152-163. https://doi.org/10.1016/j.jhealeco.2014.05.004.

North, D.C. (1990). Institutions, institutional change, and economic performance. Cambridge University Press.

North, D.C. (2005). Understanding the process of economic change. Princeton University Press.

Pamuk, S. (2007). The Black Death and the origins of the 'great divergence' across Europe, 1300-1600. European Review of Economic History, 11(3), 289317. https://doi.org/10.1017/s1361491607002031.

Piątkowski, M. (2018). Europe's growth champion: insights from the economic rise of Poland. Oxford University Press.

Pierson, P. (2004). Politics in time: history, institutions, and social analysis. Princeton University Press.

Pulejo, M., \& Querubín, P. (2020). Electoral concerns reduce restrictive measures during the Covid-19 pandemic. https://doi.org/10.3386/w27498.

Richter, A., \& Robling, P.O. (2013). Multigenerational effects of the 1918-19 influenza pandemic in Sweden. Swedish Institute for Social Research Working Paper, 5, 1-46.

Rodela, T.T., Tasnim, S., Mazumder, H., Faizah, F., Sultana, A., \& Hossain, M.M. (2020). Economic impacts of coronavirus disease (Covid-19) in developing countries. https://doi.org/10.31235/osf.io/wygpk.

Rodrik, D., Subramanian, A., \& Trebbi, F. (2004). Institutions rule: the primacy of institutions over geography and integration in economic development. Journal of Economic Growth, 9(2), 131-165. https://doi. org/10.1023/B:JOEG.0000031425.72248.85.

Sebhatu, A., Wennberg, K., Arora-Jonsson, S., \& Lindberg, S. I. (2020). Explaining the homogeneous diffusion of Covid-19 nonpharmaceutical interventions across heterogeneous countries. Proceedings of the National Academy of Sciences of the United States of America, 117(35), 21201-21208. https://doi. org/10.1073/pnas.2010625117.

Shirley, M. (2008). Institutions and development. Edward Elgar. https://doi. org/10.4337/9781848443990.

Sorci, G., Faivre, B., \& Morand, S. (2020a). Why does Covid-19 case fatality rate vary among countries. https://doi.org/10.1101/2020.04.17.20069393. 
Sorci, G., Faivre, B., \& Morand, S. (2020b). Explaining among-country variation in Covid-19 case fatality rate. Scientific Reports, 10(1), 1-11. https://doi. org/10.1038/s41598-020-75848-2.

The Economist Intelligence Unit. (2021). Democracy index 2020: in sickness and in health. Retrieved 09.09.2021 from https://www.eiu.com/n/ campaigns/democracy-index-2020.

Toye, J. (1997). The new institutional economics and its implications for development theory. In J. Harriss, J. Hunter, \& C.M. Lewis (Eds.), The new institutional economics and third world development (pp. 49-70). Routledge. https://doi.org/10.4324/9780203444290.

Tuite, A.R., Bogoch, I.I., Sherbo, R., Watts, A., Fisman, D., \& Khan, K. (2020). Estimation of Covid-2019 burden and potential for international dissemination of infection from Iran. https:// doi.org/10.1101/2020.02.24.20027375.

Tuite, A.R., Ng, V., Rees, E., Fisman, D., Wilder-Smith, A., Khan, K., \& Bogoch, I.I. (2020). Estimation of the Covid-19 burden in Egypt through exported case detection. The Lancet Infectious Diseases, 20(8), 894. https://doi. org/10.1016/S1473-3099(20)30233-4.

van Bavel, B. (2016). The invisible hand: how market economies have emerged and declined since AD 500. Oxford University Press. https: / / doi.org/10.1093/acpro f:oso/9780199608133.001.0001.

van Bavel, B. (2020). Market dominance and endogenous decline: the contribution of historical analysis. Journal of Institutional Economics, 17(1), 177-183. https://doi.org/10.1017/S1744137420000405.

van Bavel, B., \& van Zanden, J.L. (2004). The jump-start of the Holland economy during the late-medieval crisis, c.1350-c.1500. The Economic History Review, 57(3), 503-532. https://doi.org/10.1111/j.1468-0289.2004.00286.x.

World Bank. (2019). Cambodia economic update: recent economic developments and outlook. Retrieved 09.09.2021 from http://documentsl.worldbank.org/ curated/en/707971575947227090/pdf/Cambodia-Economic-Update-Upgrading-Cambodia-in-Global-Value-Chains.pdf.

World Bank. (2021a). Cambodia overview. Retrieved 09.09.2021 from https:// www.worldbank.org/en/country/cambodia/overview.

World Bank. (2021b). World development indicators. Retrieved 09.09.2021 from https://databank.worldbank.org/source/world-development-indicators.

\section{Acknowledgements}

Author contributions: author has given an approval to the final version of the article.

Funding: this research was fully funded by the author's own sources.

Note: the results of this study were presented at 4th Scientific Conference: Institutions in Theory and Practice (March 25-26, 2021, Wrocław, Poland). 
